\title{
The Smiley Prize
}

The Smiley Prize, established in honour of Donald V. Smiley (1921-1990), internationally renowned scholar of Canadian politics and a former President of the Canadian Political Science Association, will be awarded for the first time in 1992. The prize, to which is attached a monetary award in the amount of $\$ 750.00$, will be awarded biannually to the author(s) of the best book published in English or French in a field relating to the study of government and politics in Canada in the preceding two-year period. The award-winning book may be single-authored or multi-authored and will be selected by the Board of Directors of the Canadian Political Science Association, upon the recommendation of the Prize Jury. The Smiley Prize is sponsored by McGraw-Hill Ryerson publishers. Individuals who have published a book in 1990 or 1991 which is eligible for the prize should ensure that their publishers forward four copies of the book by December 31, 1991 to: The Chair, The Smiley Prize Jury, The Canadian Political Science Association, Suite 205, I Stewart Street, Ottawa, Ontario KIN $6 H 7$.

\section{Le Prix Smiley}

Le Prix Smiley a été créé en homage à Donald V. Smiley (1921-1990), le grand spécialiste de la politique canadienne dont la réputation dépassait nos frontières et un ancien président de l'Association canadienne de science politique. L'Association décernera le Prix Smiley, d'une valeur de 750 \$, pour la première fois en 1992 et par la suite à tous les deux ans à l'auteur(e, ou les auteurs) du meilleur livre publié en français ou en anglais sur un sujet traitant de la politique ou du gouvernement au Canada au cours de la période correspondante de deux ans. Le Conseil d'administration de l'Association désignera le (la ou les) lauréat(e,s) à la suite d'une recommandation du Jury du Prix Smiley. Le Prix Smiley est subventionné par les éditeurs McGraw-Hill Ryerson. Les personnes qui auraient publié en 1990 ou en 1991 selon les conditions du concours devront, pour être éligibles, signaler à leurs éditeurs de faire parvenir quatre exemplaires de leur ouvrage, avant le 31 décembre 1991 au: Président du Jury du Prix Smiley, Association canadienne de science politique, Bureau 205, l, rue Stewart, Ottawa, Ontario KIN $6 H 7$. 